\title{
Delinquência / Delinquency
}

https://doi.org/10.21814/uminho.ed.36.23

Maria João Leote de Carvalho

CICS.NOVA - Centro Interdisciplinar de Ciências Sociais, Faculdade de Ciências Sociais e Humanas da Universidade Nova de Lisboa (NOVA FCSH), Portugal 



\section{Delinquência ${ }^{3}$}

Na sua raiz etimológica, o termo delinquência (delinquere) refere-se a ato ilegal, infração (delito) ou violação das normas definidas em códigos e diplomas legais. Começou a ganhar conteúdo específico no campo da infância em Inglaterra, em 1815, um ano depois da condenação à morte de cinco crianças e foi posteriormente consagrado nos Estados Unidos da América, em 1823, pela afirmação das entidades oficiais de que adultos e crianças autores de delitos não podiam continuar a ser tratados social e juridicamente da mesma forma. Surge assim, pela primeira vez, para designar a categoria do desvio que enquadra a prática de factos qualificados pela lei penal como crime por aqueles que, pela sua idade, são considerados criminalmente inimputáveis, ou seja, a reação social de que são alvo é diferenciada da aplicada aos adultos.

Enquanto conceito reportado a uma categoria do desvio socialmente construído por referência a normas, valores e representações, a definição da delinquência está imersa em controvérsia pois varia em função do contexto sociocultural e da época a que se encontre associada. A rotulagem de um ato como delinquente decorre do estabelecido numa convenção jurídica, refletindo o compromisso entre diversas forças sociais sobre a infância e os direitos da criança.

Na sua origem estão processos e dinâmicas sociais, fatores de natureza individual e circunstâncias pessoais e coletivas em resultado da interação social, de ocorrências que são fruto da vida social e que, não só traduzem maneiras de pensar, agir e sentir individuais e grupais perante o desvio à norma social, como refletem um poder, coercivo, exterior às crianças, que

3 Este texto tem origem em projeto de investigação da autora apoiado pelaFCT-Fundação para a Ciência e Tecnologia através de Bolsa individual de Pós-Doutoramento (SFRH/BPD/116119/2016) com financiamento comparticipado pelo Fundo Social Europeu, no âmbito do POCH-Programa Operacional do Capital Humano, e por fundos nacionais do MCTES - Ministério da Ciência, Tecnologia e Ensino Superior.

This text results from the author's research project, funded by FCT - Foundation for Science and Technology through an individual Post-Doctoral Grant (SFRH/BPD/116119/2016) with co-funding from the European Social Fund, under the POCH - Human Capital Operational Programme, and from national funds of the MCTES - Ministry of Science, Technology and Higher Education. 
ganha corpo em determinadas formas de organização social e de sanções (Carvalho, 2010).

Uma questão atual diz respeito à relevância atribuída à idade com que se cometem os primeiros delitos (Loeber \& Farrington, 2001). Nas décadas de 1980-90, ganhou corpo um conjunto de pesquisas em diferentes países, parte das quais ainda hoje permanecem ativas, que têm constatado que a prática de delinquência por crianças menores de 13 anos constitui fator de risco acrescido para o desenvolvimento de trajetórias criminais crónicas, marcadas por atos de maior violência e gravidade em comparação com outras em que o início das atividades delituosas ocorreu em idade posterior. Não existe determinismo social. Nem todas as crianças que praticam atos delinquentes se mantêm neste mundo ou passam, mais tarde, para o do crime; isso acontece somente para uma minoria.

A leitura deste problema social é complexa. Conhecê-lo a partir dos contextos sociais onde se produz, dos atores sociais, as crianças na qualidade de agressoras ou as vítimas nela envolvidos é uma coisa, conhecê-la a partir da informação recenseada nos sistemas oficiais de justiça e de segurança, dos instrumentos de reação social de que uma sociedade dispõe no exercício do controlo social, é outra. Trata-se de um fenómeno plural, que encerra em si uma multiplicidade de expressões e tanto pode ser analisado em termos do funcionamento de padrões individuais e coletivos como centrar-se na evolução histórica e social dos modelos de intervenção e prevenção da delinquência num determinado contexto.

O termo delinquência tem sido associado ao qualificador "juvenil", mas nem sempre se reporta, de modo exclusivo, a crianças mais velhas. Em vários países, os mecanismos de controlo social formal colocam crianças em idades baixas (7-10 anos) em patamar similar ao das mais velhas (acima dos 13 anos), o que se traduz numa grande abrangência e amplitude etária podendo, sob a mesma capa, ocultar-se uma diversidade de situações. A recorrência no uso deste qualificador deve-se à generalização relativa de fenómenos de desvio no final da infância em correlação com as especificidades do desenvolvimento biopsicossocial da criança. A literatura evidencia que a taxa de prevalência na prática de ilícitos aumenta a partir dos 9-10 anos até atingir um pico entre os 15 e os 19 anos, a partir da qual tende a diminuir.

Mesmo perante o estabelecimento de metas a nível europeu visando a prevenção do envolvimento de crianças na delinquência, não é consensual a importância atribuída a este problema social. Assiste-se, por vezes, à sua 
relativização por parte de interventores sociais e decisores políticos através da tomada de posições que pretendem ignorar a sua existência (Imloul, 2008). Alguns justificam esta atitude pelo reduzido número de crianças identificadas pelas autoridades policiais ou judiciárias, desvalorizando que recorrentemente os seus modos de vida encerram o não cumprimento dos Direitos da Criança consubstanciados em convenções internacionais. Mais do que ficar por um olhar restrito às estatísticas oficiais, há que ponderar uma outra dimensão desta problemática, eminentemente de natureza social, que inclui o conhecimento sobre o que escapa à ação oficial e em relação ao qual se desconhece a verdadeira dimensão.

A delinquência não é um fenómeno exclusivo das sociedades contemporâneas; existiu desde sempre e em todos os grupos sociais, variando simplesmente a forma como se caracteriza e se torna visível ao longo dos tempos. De igual modo, também a preocupação social sobre este problema social não é nova. Porém, nos dias de hoje, adquire um especial relevo pelas questões que coloca em causa, umas aparentemente recentes, outras mais antigas, mas eventualmente com novos contornos decorrentes da evolução da realidade social. Umas e outras encerram importantes desafios e renovadas tensões para análise no campo da Sociologia da Infância.

\section{Delinquency}

In its etymological root, the term delinquency (delinquere) refers to an illegal act, infraction (offence) or violation of the rules defined in codes and legal texts. It began to gain specific content in the field of childhood in England, in 1815, a year after the death sentence of five children. It was subsequently consecrated in the United States of America, in 1823, by the statement of official entities that adult and child authors of offences could not continue to be treated socially and legally in the same way. The term delinquency, thus, appeared, for the first time, to designate the category of deviation that frames the practice of facts qualified by criminal law as a crime, by those who, by their age, are considered not criminally responsible, which means that the social reaction they incur is differentiated from the one applied to adults.

As a concept related to a category of socially constructed deviation by reference to norms, values and representations, the definition of delinquency is immersed in controversy since it varies depending on the socio-cultural context and the period with which it is associated. The labelling of an act as 
delinquent stems from what is established in a legal convention, reflecting the commitment between different social forces about childhood and the rights of the child.

At its origin are social processes and dynamics, factors of an individual and personal nature and collective circumstances resulting from of social interaction, occurrences that are the result of social life and that not only translate individual and group ways of thinking, acting and feeling in the face of deviation from the social norm, but also reflect a coercive power, external to children, which takes shape in certain forms of social organization and sanctions (Carvalho, 2010).

A current issue concerns the relevance attributed to the age at which the first offences are committed (Loeber \& Farrington, 2001). In the 1980s-90s, a series of studies in different countries took shape, part of which still remain active today. These studies have found that the practice of delinquency by children under 13 years of age constitutes an increased risk factor for the development of chronic criminal trajectories, marked by acts of greater violence and gravity compared to others in which the beginning of criminal activities occurred at a later age. There is no social determinism. Not all children who commit delinquent acts remain in this realm or later move on to crime; this happens for a minority only.

Understanding this social problem is complex. Knowing and understanding it from the social contexts where it takes place, from the social actors, from the children as aggressors or the victims involved in it, is one thing. To know it from the information recorded in the official justice and security systems, the social reaction instruments that a society uses to exercise social control, is another. It is a plural phenomenon, which contains a multiplicity of expressions and can be analysed both in terms of the functioning of individual and collective patterns and the focus on the historical and social evolution of the models of intervention and prevention of delinquency in a given context.

The term delinquency has been associated with the qualifier "juvenile", but it does not always refer exclusively to older children. In several countries, formal social control mechanisms place children at a young age (7-10 years) on a similar level to that of older people (over 13 years), This translates into a wide age range and, within the same framework, conceals a variety of situations. The recurrence of the use of this qualifier is due to the relative generalization of deviation phenomena in late childhood in 
correlation with the specifics of the child's bio - psychosocial development. The literature shows that the prevalence rate in the practice of illicit acts increases from 9-10 years old until it reaches a peak between 15 and 19 years old, after which it tends to decrease.

Even when setting goals at a European level to prevent the involvement of children in delinquency, there is no consensus on the importance attached to this social problem. Sometimes, social actors and political decision makers relativise it through taking positions that intend to ignore its existence (Imloul, 2008). Some justify this attitude by the small number of children identified by the police or judicial authorities, undervaluing the knowledge that their way of life repeatedly means the non-compliance with the Rights of the Child embodied in international conventions. More than just looking at official statistics, it is necessary to consider another dimension of this problem, predominantly of a social nature, which includes knowledge about what escapes official action and whose true dimension is not known.

Delinquency is not a phenomenon exclusive to contemporary societies; it has always existed and has been present in all social groups, simply changing in terms of the way it is characterized and becomes visible over time. Likewise, social concern about this social problem is also not new. However, nowadays, it acquires a special relevance because of the questions that emerge, some apparently recent, others older, but eventually with new dimensions resulting from the evolution of social reality. Some of these contain important challenges and renewed tensions for analysis in the field of Sociology of Childhood.

\section{Referências / References}

Carvalho, M. J. L. (2010). Do Outro Lado da Cidade. Crianças, Socialização e Delinquência em Bairros de Realojamento. [Dissertação de Doutoramento não publicada]. Faculdade de Ciências Sociais e Humanas, Universidade NOVA de Lisboa, Portugal. Disponível em: http://run.unl.pt/ handle/10362/6132

Imloul, S. (2008). Enfants Bandits. La Violence des 3-13 Ans dans les Banlieues. Paris: Éditions du Panama.

Loeber, R. \& Farrington, D. (2001). Child Delinquents: Development, Interventions and Service Needs, Thousand Oaks, Califórnia: Sage Publications. 